\title{
Efficiency of managing liabilities of enterprises of different types of economic activities
}

\author{
Assoc. Prof., DrS Andrii Sakhno성, Assoc. Prof., PhD Iryna Salkova², Assoc. Prof., PhD
} Nataliia Polishchuk ${ }^{3}$, Assoc. Prof., PhD Lesia Kucher ${ }^{4}$, Assoc. Prof., PhD Inna Stashko ${ }^{5}$

\begin{abstract}
The article substantiates approaches to making decisions of obligations management in the conditions of increasing the assets by types of economic activity in Ukraine. The possibility of using correlationregression analysis to determine the most favorable variations (in relation of density) between the effective indicator (types of assets) and production factors (types of liabilities) has been proved. A method of analyzing the operating environment is applied to identify the shortest possible reduction in current and long-term liabilities and maximize the volume of current assets. It was found that (i) the most efficient type of economic activity due to the increase in current assets in Ukraine was administrative and support service activities (0.90), the least efficient - agriculture, forestry and fisheries (0.47); (ii) education and training activities (0.93) are the most effective types of economic activity due to reduce liabilities, and health and social assistance (0.44) are the least effective. The results of the study can be used in planning the sustainable development of different types of economic activity.
\end{abstract}

Key words: liabilities, assets, types of economic activities, entities, profit, efficiency, Ukraine.

\section{Introduction}

The formation of assets of an economic entity occurs in the process of development of the national economy of the state. As a consequence, the government must take into account the specificities of each type of economic activity, depending on the ability to create assets, achieve profitability and meet the needs of society.

The needs of society are the main factor for which the state generates profits and increases assets, but the economic feasibility and existing competition practices prove that the opportunities of different industries are unequal, and therefore arises the problem of finding and implementing approaches to determine the level of resource adequacy and the justification of the achieved result. In today's economic relations, it is not always advisable to consider the expediency of development of certain types of economic activity in terms of profit. The financial result only reflects temporary success and does not allow us to speak about existing trends in the national economy.

Based on the mentioned above, the assessment of trends in the national economy should be made on the basis of relative indicators - through the correlation of assets and liabilities of the balance taking into account the method of analysis of the operating environment.

The activity of an entity is possible with the availability of the resources, that is own and borrowed funds. The importance of the latter is particularly important, because in a market economy, the development of economic activity is possible in the presence

\footnotetext{
1,3,5 Vinnytsia Finance and Economics University, Vinnytsia, Ukraine.

2 Vinnytsia National Agrarian University, Vinnytsia, Ukraine.

${ }^{4}$ Kharkiv National Agrarian University named after V. V. Dokuchayev, Kharkiv, Ukraine.
} 
of borrowings that create obligations.

There are many definitions in the domestic and foreign practices regarding the nature of the liability arising. The context in which commitment is explored is important. It is the most convenient to treat an obligation as a duty or a responsibility to act in a certain way [1]. B. Ryan combines the notion of «obligation» with the concepts of «fulfillment» and «liquidation» [2]. V. Zelheim and I. Shalov consider liabilities as part of an asset because it is the property of the enterprise [3]. A time commitment factor is a dependency on a future event arising from a past agreement [4].

Commitment is a problem for the entity, and therefore it is necessary to reduce them in view of the impact on the volume of assets, and therefore the measurement of liabilities should be carried out as a measure of effectiveness - because of the ability to reduce liabilities and increase assets. A. Neely noted that in the academic community, research into determining the effectiveness of activities is carried out by representatives of functionally diverse fields of knowledge. Specialists in such fields as accounting, economics, human resources management, marketing, operational management, psychology and sociology are all studying this problem [5, p. 2].

The works of many scholars are devoted to efficiency evaluation of assets and liabilities management, as well as their components. In particular, R. A. Chemchykalenko, O. Ye. Maiboroda, and A. V. Liutkina investigate directly the problem of efficiency of managing the assets and liabilities of enterprises [6]. O. Krukovs'ka explores the issue of formation of the initial value of inventories of own production [7]. Capital as the aggregate potential of the enterprise was explored in the work of I. Demjanyuk, D. Vorobei [8]. Accounts receivable and payables as the main regulators of the circulating capital of the enterprise are covered in the work of N. L. Marusyak [9]. Issues of management of accounts payable as a factor of providing financial and economic security of the enterprise are devoted to the work O. M. Gubarik, A. V. Guban [10]. Among foreign scientists, the issues of asset and liability management have been studied by R. Black, K. Brown, and J. Moloney [11], S. Gerd [12], V. Rensburg, J. Singleton Janse [13]. Obligations and assets management is dedicated to the works of D. Mehta, H. Gay-Fung [14] and Yu. Romanyuk [15]. The accounting for the fair value of financial liabilities is reflected in the work of W. Marsh [16].

\section{Materials and Methods}

The purpose of the article is to identify and implement approaches to managing liabilities in the context of the need to form assets by types of economic activity in the Ukrainian economy, to maximize efficiency by reducing liabilities and increasing assets.

Using the method of analysis of the operating environment allows us to build the boundary of the production capacity of the entity and optimize the performance indicator, which is usually the volume of products sold and factors of production (capital and labor). This method is based on the use of a coordinate system where, on the abscissa and ordinate axes, relative indicators are plotted - the coefficients of coverage of income from sales of labor and capital expenditure $(\mathrm{L} / \mathrm{Y}$ and $\mathrm{K} / \mathrm{Y})$, where $\mathrm{Y}$ is the revenue from sales of products, $\mathrm{L}-$ labor costs; $\mathrm{K}$ is the cost of capital. 


\section{Results}

It is reasonable to use the principles of the method of analysis of the operating environment to assess the need for the formation of assets of business entities and optimization of their liabilities. Using the data of the State Statistics Service of Ukraine [17], let us consider the sections of assets and liabilities of economic entities by types of economic activity (Classificator of Types of Economic Activity, CTEA - 2010) (Table 1).

Table 1: Indicators of balance of Ukrainian enterprises by types of economic activity, 2017, mln $\mathrm{UAH}$

\begin{tabular}{|c|c|c|c|c|c|c|}
\hline No & Type of economic activity & $\begin{array}{l}\text { Non- } \\
\text { current } \\
\text { assets } \\
\text { (NCA) }\end{array}$ & $\begin{array}{l}\text { Current } \\
\text { assets } \\
\text { (CA) }\end{array}$ & $\begin{array}{c}\text { Equity } \\
\text { (Eq) }\end{array}$ & $\begin{array}{l}\text { Long-term } \\
\text { liabilities } \\
\text { and } \\
\text { securities } \\
\text { (LL) }\end{array}$ & $\begin{array}{l}\text { Current } \\
\text { liabilities } \\
\text { and } \\
\text { securities } \\
\text { (CL) }\end{array}$ \\
\hline 1 & Agriculture, forestry and fisheries & 272513.7 & 639025.2 & 436337.7 & 59080.5 & 416146.2 \\
\hline 2 & Mining and quarrying & 293832.1 & 279377.1 & 184964.1 & 78106.7 & 310165.3 \\
\hline 3 & Manufacturing industry & 583778.4 & 1194397.9 & 118708.5 & 329400.3 & 1330491.8 \\
\hline 4 & $\begin{array}{l}\text { Supply of electricity, gas, steam } \\
\text { and air conditioning }\end{array}$ & 437626.2 & 289741.8 & 215713.3 & 170961.0 & 340869.3 \\
\hline 5 & $\begin{array}{l}\text { Water supply, sewerage, waste } \\
\text { management }\end{array}$ & 45737.8 & 17487.6 & 30041.3 & 10370.0 & 22831.9 \\
\hline 6 & Construction & 115884.1 & 253823.1 & -20102.4 & 104965.0 & 285343.0 \\
\hline 7 & $\begin{array}{l}\text { Wholesale and retail trade; repair } \\
\text { of motor vehicles and } \\
\text { motorcycles }\end{array}$ & 276868.8 & 1715815.4 & 26231.7 & 295140.6 & 1671853.9 \\
\hline 8 & $\begin{array}{l}\text { Transportation, warehousing, } \\
\text { postal and courier activities }\end{array}$ & 784171.7 & 217451.3 & 612569.1 & 143404.2 & 245836.5 \\
\hline 9 & $\begin{array}{l}\text { Temporary accommodation and } \\
\text { catering }\end{array}$ & 24601.9 & 14725.9 & -2712.3 & 17861.6 & 24206.3 \\
\hline 10 & $\begin{array}{l}\text { Information and } \\
\text { telecommunications }\end{array}$ & 81216.5 & 66555.3 & 28524.8 & 45916.7 & 75197.5 \\
\hline 11 & Financial and insurance & 117962.1 & 233166.6 & 2301.7 & 92244.1 & 134627.0 \\
\hline 12 & Real estate transactions & 356086.3 & 239267.9 & -24238.7 & 250585.3 & 369700.3 \\
\hline 13 & $\begin{array}{l}\text { Professional, scientific and } \\
\text { technical activities }\end{array}$ & 589283.0 & 385866.1 & 488446.3 & 83496.9 & 403256.6 \\
\hline 14 & $\begin{array}{l}\text { Administrative and support } \\
\text { service activities }\end{array}$ & 279204.8 & 84421.4 & 221003.0 & 33297.7 & 109652.7 \\
\hline 15 & Education & 2126.4 & 1087.5 & 2067.2 & 105.5 & 1041.3 \\
\hline 16 & Health care and social assistance & 10696.1 & 5176.5 & 4662.9 & 4254.0 & 6956.2 \\
\hline 17 & $\begin{array}{l}\text { Arts, sports, entertainment and } \\
\text { recreation }\end{array}$ & 27541.0 & 9816.0 & 9358.0 & 11480.6 & 16525.0 \\
\hline 18 & Provision of other services & 4151.9 & 3614.8 & 2621.9 & 306.7 & 4838.2 \\
\hline
\end{tabular}

Source: based on indicators of balance sheets of economic activities, 2017.

Taking into account that the method of analysis of the operating environment involves the use of only positive values for efficiency evaluation, it is necessary to 
exclude from this set of economic activities such as construction; temporary accommodation and catering; and real estate operations, since their values of equity are negative.

Based on fifteen types of economic activities, we'll determine the regression equations and correlation coefficients for the existing data set ( $\mathrm{Y}$ is the value of noncurrent and current assets, $\mathrm{X}$ is the value of equity, long-term liabilities and securities, current liabilities and securities) (Table 2).

Table 2: Regression equation and correlation coefficients of assets' dependence on equity, longterm and current liabilities during division the Ukrainian enterprises by types of economic activity, 2017

\begin{tabular}{|l|c|c|c|}
\hline \multicolumn{1}{|c|}{ Indicators } & Equity & $\begin{array}{c}\text { Long-term liabilities } \\
\text { and securities }\end{array}$ & $\begin{array}{c}\text { Current liabilities and } \\
\text { securities }\end{array}$ \\
\hline Non-current & $\mathrm{Y}=1.0032 \mathrm{X}+94366$ & $\mathrm{Y}=1.5207 \mathrm{X}+116150$ & $\mathrm{Y}=0.2257 \mathrm{X}+177194$ \\
assets & $\mathrm{R}=0.81$ & $\mathrm{R}=0.63$ & $\mathrm{R}=0.45$ \\
\hline Current assets & $\mathrm{Y}=0.1854 \mathrm{X}+313407$ & $\mathrm{Y}=4.2001 \mathrm{X}-37265$ & $\mathrm{Y}=0.9816 \mathrm{X}+9757.3$ \\
$\mathrm{R}=0.07$ & $\mathrm{R}=0.88$ & $\mathrm{R}=0.99$ \\
\hline
\end{tabular}

Source: calculated by the authors.

All types of economic activities have different features of product manufacturing, service delivery, and cost generation. Taking into account the impossibility of comparing the activity of processing enterprises with the activity of educational institutions in the usual mode, we'll use the approach proposed by G. Debreu [18] and M. J. Farrell [19], the content of which is that an acceptable method of comparisons between these types of economic activity is the ultimate method of achieving efficiency. In this context, the indicators of analysis are completely justified, since profit orientation is not decisive for all entities. For example, institutions providing educational, medical, and arts services are not always aimed at generating profits.

Considering the above mentioned features and analyzing the relationships that have the highest correlation coefficient, we'll construct coefficients of covering the current liabilities by current assets (CL/CA) and long-term liabilities (LL/CA) for fifteen types of economic activity (Table 3).

Using these coefficients, it is possible to determine the efficiency of working capital formation and the effectiveness of securing current and long-term liabilities (Fig. 1). The abscissa axis is formed by the values of coefficients of covering the current liabilities by current assets, the ordinate axis is formed by the values of coefficients of covering the long-term liabilities by current assets.

The numbers of each type of economic activity indicate all positions on the chart (Fig. 1). The line 9-1-15 is a line of efficiency from reduction of current and longterm liabilities. The line 9-14-15 is the line of efficiency from increasing of current assets.

The coefficient characterizing the effectiveness of reducing liabilities is calculated by the ratio of such distances (for example, item 4 «Supply of electricity, gas, steam and air conditioning»): 0A/04. The coefficient characterizing the efficiency of increasing current assets is calculated by the ratio of such distances (for example, item 4 «Supply of electricity, gas, steam and air conditioning»): 04/0C. 
Table 3: Coefficients of covering of long-term and current liabilities by current assets at Ukrainian enterprises by types of economic activity, 2017

\begin{tabular}{|c|l|c|c|}
\hline No & \multicolumn{1}{|c|}{ Type of economic activity } & CL/CA & LL/CA \\
\hline 1 & Agriculture, forestry and fisheries & 0.65 & 0.09 \\
\hline 2 & Mining and quarrying & 1.11 & 0.28 \\
\hline 3 & Manufacturing industry & 1.11 & 0.27 \\
\hline 4 & Supply of electricity, gas, steam and air conditioning & 1.18 & 0.59 \\
\hline 5 & Water supply, sewerage, waste management & 1.31 & 0.59 \\
\hline 6 & $\begin{array}{l}\text { Wholesale and retail trade; repair of motor vehicles and } \\
\text { motorcycles }\end{array}$ & 0.97 & 0.17 \\
\hline 7 & Transportation, warehousing, postal and courier activities & 1.13 & 0.66 \\
\hline 8 & Information and Telecommunications & 1.13 & 0.69 \\
\hline 9 & Financial and insurance & 0.58 & 0.39 \\
\hline 10 & Professional, scientific and technical activities & 1.04 & 0.21 \\
\hline 11 & Administrative and support service activities & 1.30 & 0.39 \\
\hline 12 & Education & 0.96 & 0.10 \\
\hline 13 & Health care and social assistance & 1.34 & 0.82 \\
\hline 14 & Arts, sports, entertainment and recreation & 1.68 & 1.17 \\
\hline 15 & Provision of other services & 1.34 & 0.08 \\
\hline
\end{tabular}

Source: calculated by the authors.

Thus, the line $9-15$ is a line that divides two lines of efficiency into two common for them positions 9 (Financial and insurance activities) and 15 (Provision of other services). Point B is the optimal position for efficient use of current assets and securing liabilities.

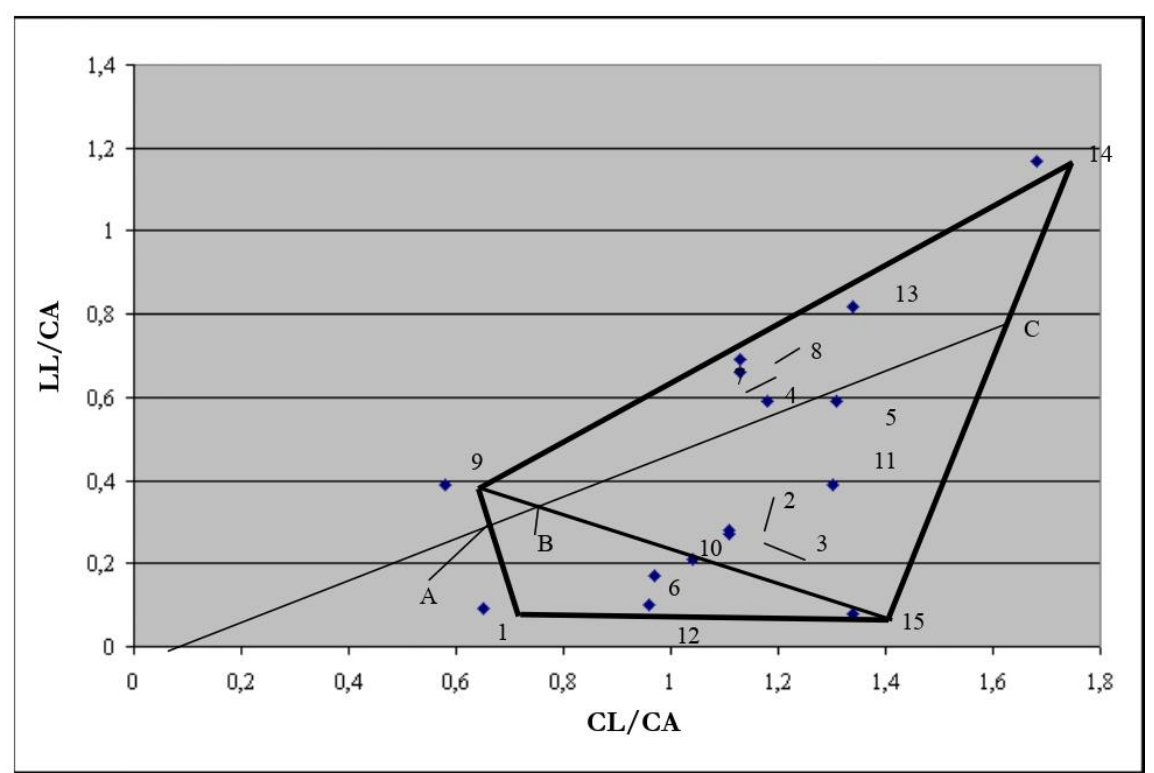

Figure 1: Analysis of options for the formation of current assets due to the impact of current and long-term liabilities of Ukrainian enterprises by types of economic activity, 2017

Source: built by the authors. 
Positions of effective economic activities have a coefficient equal to one. The most efficient type of economic activity due to the increase in current assets is the administrative and support service activities (position 11, coefficient 0.90), the least effective is agriculture, forestry and fisheries (position 1, coefficient 0.47) (Table 4).

The most effective type of economic activity from the reduction of liabilities is activity in the field of education (position 12, coefficient 0.93 ), the least effective is health and social assistance (position 13, coefficient 0.44) (Table 4).

Table 4: Efficiency of Ukrainian business entities by types of economic activity, 2017

\begin{tabular}{|c|c|c|c|}
\hline \multirow[b]{2}{*}{ No } & \multirow[b]{2}{*}{ Type of economic activity } & \multicolumn{2}{|c|}{ Coefficient that characterizes } \\
\hline & & $\begin{array}{c}\text { Efficiency } \\
\text { from increase } \\
\text { in current } \\
\text { assets }\end{array}$ & $\begin{array}{l}\text { Efficiency } \\
\text { from liabilities } \\
\text { reduction }\end{array}$ \\
\hline 1 & Agriculture, forestry and fisheries & 0.47 & 1.00 \\
\hline 2 & Mining and quarrying & 0.78 & 0.57 \\
\hline 3 & Manufacturing industry & 0.78 & 0.57 \\
\hline 4 & Supply of electricity, gas, steam and air conditioning & 0.75 & 0.51 \\
\hline 5 & Water supply, sewerage, waste management & 0.86 & 0.46 \\
\hline 6 & $\begin{array}{l}\text { Wholesale and retail trade; repair of motor vehicles and } \\
\text { motorcycles }\end{array}$ & 0.70 & 0.66 \\
\hline 7 & $\begin{array}{l}\text { Transportation, warehousing, postal and courier } \\
\text { activities }\end{array}$ & 0.70 & 0.51 \\
\hline 8 & Information and telecommunications & 0.69 & 0.52 \\
\hline 9 & Financial and insurance & 1.00 & 1.00 \\
\hline 10 & Professional, scientific and technical activities & 0.75 & 0.62 \\
\hline 11 & Administrative and support service activities & 0.90 & 0.48 \\
\hline 12 & Education & 0.70 & 0.93 \\
\hline 13 & Health care and social assistance & 0.81 & 0.44 \\
\hline 14 & Arts, sports, entertainment and recreation & 1.00 & 1.00 \\
\hline 15 & Provision of other services & 1.00 & 1.00 \\
\hline
\end{tabular}

Source: calculated by the authors.

The coefficients of liability management and the formation of current assets at economic entities by economic activities are projections of the positions of inefficient economic activities on lines 9-1-15 and 9-14-15 (for example, points $A$ and $C$ for economic activity «Supply of electricity, gas, steam and air conditioning») (Table 5). The calculation of the projection of positions allows us to determine the coefficients for both current and long-term liabilities.

Knowing the coefficients of liability management and the formation of current assets, it is possible to calculate the value of liabilities and current assets of economic entities by types of economic activity (Table 6). For example, for the fourth position of economic activity «Supply of electricity, gas, steam and air conditioning», the algorithm for calculating the possibility of reducing long-term liabilities with such indicator of current assets would be: 
- the value of long-term liabilities based on the maximum acceptable coefficient of liabilities management in the calculation of the value of current assets: $\mathrm{LL}=0.58 \cdot 289741.8=168050.2 \mathrm{mln} \mathrm{UAH}$;

- the possibility of reducing long-term liabilities with this indicator of current assets: $170961.0-168050.2=2910.8 \mathrm{mln} \mathrm{UAH}$.

Table 5: Coefficients of liabilities management and formation of current assets of economic entities of Ukraine by types of economic activity, 2017

\begin{tabular}{|c|c|c|c|c|c|}
\hline \multirow[t]{2}{*}{ No } & \multirow[t]{2}{*}{ Type of economic activity } & \multicolumn{2}{|c|}{$\begin{array}{c}\text { Coefficient of } \\
\text { management of } \\
\text { liabilities in the } \\
\text { calculation of the value } \\
\text { of current assets }\end{array}$} & \multicolumn{2}{|c|}{$\begin{array}{c}\text { Coefficient of current } \\
\text { assets formation in } \\
\text { calculating the value } \\
\text { of liabilities }\end{array}$} \\
\hline & & $\begin{array}{l}\text { long- } \\
\text { term }\end{array}$ & $\begin{array}{c}\text { current } \\
\text { ones }\end{array}$ & $\begin{array}{l}\text { long- } \\
\text { term }\end{array}$ & $\begin{array}{l}\text { current } \\
\text { ones }\end{array}$ \\
\hline 1 & Agriculture, forestry and fisheries & - & - & 0.18 & 1.36 \\
\hline 2 & Mining and quarrying & 0.16 & 0.62 & 0.36 & 1.42 \\
\hline 3 & Manufacturing industry & 0.15 & 0.64 & 0.30 & 1.41 \\
\hline 4 & $\begin{array}{l}\text { Supply of electricity, gas, steam and air } \\
\text { conditioning }\end{array}$ & 0.58 & 0.85 & 0.78 & 1.55 \\
\hline 5 & Water supply, sewerage, waste management & 0.27 & 0.60 & 0.68 & 1.53 \\
\hline 6 & $\begin{array}{l}\text { Wholesale and retail trade; repair of motor } \\
\text { vehicles and motorcycles }\end{array}$ & 0.10 & 0.64 & 0.24 & 1.39 \\
\hline 7 & $\begin{array}{l}\text { Transportation, warehousing, postal and } \\
\text { courier activities }\end{array}$ & 0.33 & 0.58 & 0.93 & 1.61 \\
\hline 8 & Information and telecommunications & 0.35 & 0.59 & 0.99 & 1.63 \\
\hline 9 & Financial and insurance & - & - & - & - \\
\hline 10 & $\begin{array}{l}\text { Professional, scientific and technical } \\
\text { activities }\end{array}$ & 0.13 & 0.64 & 0.27 & 1.40 \\
\hline 11 & $\begin{array}{l}\text { Administrative and support service } \\
\text { activities }\end{array}$ & 0.18 & 0.63 & 0.42 & 1.45 \\
\hline 12 & Education & 0.08 & 0.78 & 0.15 & 1.36 \\
\hline 13 & Health care and social assistance & 0.35 & 0.59 & 0.99 & 1.63 \\
\hline 14 & Arts, sports, entertainment and recreation & 0.39 & 0.58 & - & - \\
\hline 15 & Provision of other services & - & - & - & - \\
\hline
\end{tabular}

Source: calculated by the authors.

Similarly, they calculate the possibility of reducing current liabilities.

The algorithm for calculating the possibility of increasing current assets by management of long-term liabilities is as follows:

- the value of current assets on the basis of the maximum acceptable coefficient of formation of current assets in the calculation of the value of long-term liabilities: $\mathrm{OA}=170961.0: 0.78=219180.8 \mathrm{mln} \mathrm{UAH}$;

- the possibility of increasing current assets with this indicator of long-term liabilities: $219180.8+289741.8=508922.6 \mathrm{mln} \mathrm{UAH}$. 
Table 6: Liabilities and current assets by respective coefficients at Ukrainian enterprises by types of economic activity in 2017, mln UAH

\begin{tabular}{|c|l|c|c|c|c|}
\hline \multirow{2}{*}{ No } & \multicolumn{1}{|c|}{ Type of economic activity } & \multicolumn{2}{c|}{ Liabilities } & \multicolumn{2}{c|}{$\begin{array}{c}\text { Current assets for } \\
\text { liabilities }\end{array}$} \\
\cline { 3 - 6 } & \multicolumn{1}{|c|}{$\begin{array}{c}\text { long- } \\
\text { term }\end{array}$} & $\begin{array}{c}\text { current } \\
\text { ones }\end{array}$ & $\begin{array}{c}\text { long- } \\
\text { term }\end{array}$ & $\begin{array}{c}\text { current } \\
\text { ones }\end{array}$ \\
\hline 1 & Agriculture, forestry and fisheries & - & - & 967250.2 & 945015.1 \\
\hline 2 & Mining and quarrying & 33406.4 & 136951.5 & 496340.2 & 497803.4 \\
\hline 3 & Manufacturing industry & 150240.6 & 566077.2 & 2292399 & 2138009 \\
\hline 4 & $\begin{array}{l}\text { Supply of electricity, gas, steam and air } \\
\text { conditioning }\end{array}$ & 29108.0 & 94588.8 & 508922.6 & 509657.5 \\
\hline 5 & Water supply, sewerage, waste management & 5648.4 & 12339.3 & 32737.6 & 32410.4 \\
\hline 6 & $\begin{array}{l}\text { Wholesale and retail trade; repair of motor } \\
\text { vehicles and motorcycles }\end{array}$ & 123559.1 & 573732.1 & 2945568 & 2918588 \\
\hline 7 & $\begin{array}{l}\text { Transportation, warehousing, postal and } \\
\text { courier activities }\end{array}$ & 71645.3 & 119714.8 & 371649.4 & 370144.8 \\
\hline 8 & Information and telecommunications & 22622.3 & 35929.9 & 112935.8 & 112688.7 \\
\hline 9 & Financial and insurance & - & - & - & - \\
\hline 10 & Professional, scientific and technical activities & 33334.3 & 156302.3 & 695113.9 & 673906.5 \\
\hline 11 & Administrative and support service activities & 18101.9 & 56467.2 & 163701.6 & 160043.9 \\
\hline 12 & Education & 18.50 & 193.1 & 1790.8 & 1853.2 \\
\hline 13 & Health care and social assistance & 2442.2 & 3902.1 & 9473.5 & 9444.1 \\
\hline 14 & Arts, sports, entertainment and recreation & 7652.4 & 10831.7 & - & - \\
\hline 15 & Provision of other services & - & - & - & - \\
\hline
\end{tabular}

Source: calculated by the authors.

Similarly, they calculate the possibility of increasing current assets by calculating the value of current liabilities. These results are of great practical importance in the context of financial support for sustainable development [20].

\section{Conclusions}

The results of the study made it possible to identify the needs of economic entities of different types of economic activity by comparing the productive resource and the performance indicator by the method of analyzing the operating environment. In particular, the study of options for the formation of current assets through the impact of current and long-term liabilities in Ukrainian enterprises by types of economic activity showed that the most effective type of economic activity due to the increase in current assets is the activity in the field of administrative and support services (position 11, coefficient 0.9), the least effective is agriculture, forestry and fisheries (position 1, coefficient 0.47 ). At the same time, the most effective type of economic activity due to liabilities reduction is education (position 12, coefficient 0.93), and the least effective is health and social assistance (position 13, coefficient 0.44). Thus, planning the development of economic activities in the context of the national economy, by the results of the previous year we can determine the values of increase in current assets and decrease in liabilities. The results of the study can be used in planning the sustainable 
development of different types of economic activity.

Further areas of study are: identifying patterns of changes in the context of noncurrent assets by analyzing the operating environment and identifying opportunities for optimization, not from the point of view of maximization, but from the point of view of the rational relationship between assets and liabilities.

\section{References}

1. The conceptual basis of the financial statements of the IASB; Standard, International Document, Concept by 01.09.2010. Available at: http://zakon2rada.gov.ua/laws/show/929_009/page.

2. Ryan, B. (1998). Stratehycheskyi uchet dlia rukovodytelia [Strategic Management Accounting]. Audit, UNITY, Moscow, Russia. 616 p.

3. Zelheim, V. N. (1919). Schetovodstvo potrebytelnukh obshchestv po amerykanskoi dvoinoi systeme (dlia srednykh o-v) [Accounting of consumer societies according to the American binary system (for medium-sized societies)]. Odessa, Ukraine. 208 p.

4. Needles, B. (2004). Pryntsypu bukhbalterskoho ucheta [Accounting Principles]. Finance and Statistics, Moscow, Russia. 496 p.

5. Neely, A. ed., (2007). Business Performance Measurement: Unifying Theory and Integrating Practice. 2nd ed. Cambridge University Press: Cambridge, UK.

6. Chemchykalenko, R. A., Maiboroda, O. Ye., Liutkina, A. V. (2017). Evaluating the effectiveness of asset and liability management of the enterprises. Economy and society, vol. 11, p. 91.

7. Krukovs'ka, E. (2016). Formation of initial cost of stocks of own production. Agricultural and Resource Economics: International Scientific E-Journal [Online], vol. 2, no. 2, pp. 5-16. Available at: http://arejournal.com.

8. Demjanyuk, I. and Vorobei, D. (2016). Capital as a basis of account for comprehensive potential enterprise: theoretical aspects. Agricultural and Resource Economics: International Scientific E-Journal [Online], vol. 2, no. 3, pp. 75-87. Available at: http://are-journal.com.

9. Marusyak, N. L. (2010). Accounts receivable and payables as the main regulators of the circulating capital of the enterprise. Bulletin of Khmelnitsky National University, vol. 2, no. 2, pp. 139-142.

10. Gubarik, O. M. and Guban, A. V. (2017). Management of accounts payable as a factor of providing financial and economic security of the enterprise. Young scientist, no. 10(50), pp. 871-874.

11. Black, R., Brown, K. and Moloney, J. (2003). Asset and liability management: what does the future have in store? Balance Sheet, vol. 11, no. 2, pp. 32-38. https://doi.org/10.1108/09657960310480651.

12. Gerd, S. (1995). An analytical approach to asset / liability performance measurement. Fixed income investment edited by Thomas Ho Irwin Professional Publishing. Pp. 205-229.

13. Rensburg, V., Singleton, Janse J. (2008). The integration of performance measurement and asset-andliability management. Available at: https:// repository.nwu.ac.za/handle/10394/2602.

14. Mehta, D., Gay-Fung, H. (2004). Asset and Liability Management. International Bank Management, chapter 9. Pp. 249-278. https://doi.org/10.1002/9780470759240.ch9.

15. Romanyuk, Yu. (2010). Asset-Liability Management: An Overview Discussion Paper / Document d'analyse. Discussion Paper 2010-10. Bank of Canada, Ottawa, Ontario, Canada. Available at: https://www.banqueducanada.ca/wp-content/uploads/2010/08/dp10-10.pdf.

16. Marsha, W. (2000). Fair-value accounting for financial liabilities. The Fair Value of Insurance Business, edited by Irwin Vanderhoof and Edward Altman. Kluwer Academic Publisher.

17. The official site of State Statistics Service of Ukraine. Available at: http://www.ukrstat.gov.ua.

18. Debreu, G. (1951). The coefficient of resource utilization. Econometrica, vol. 9(3), pp. 273-292. https://doi.org/10.2307/1906814

19. Farrell, M. J. (1957). The measurement of productive efficiency. Journal of the Royal Statistical Society, Series A, 120(3), pp. 253-290. https://doi.org/10.2307/2343100.

20. Kirieieva, E. A., Pryshliak, N. V., Shamanska, O. I., Salkova, I. Yu. and Kucher, A. V. (2019). Strategic priorities and financial support of Ukrainian agricultural sector development. International Journal of Ecological Economics \& Statistics, vol. 40, no. 2, pp. 25-37. 